\title{
PEMBENTUKAN KARAKTER MELALUI POLA ASUH DEMOKRATIS UNTUK MENCEGAH KECANDUAN GADGET REMAJA DI ERA REVOLUSI INDUSTRI 4.0
}

\author{
CHARACTER FORMATION THROUGH DEMOCRATIC PARENTING \\ TO PREVENT ADOLESCENT GADGET ADDICTION \\ IN THE INDUSTRIAL REVOLUTION 4.0
}

Oleh:

Sri Widayani ${ }^{1}$

Kamsih Astuti ${ }^{2}$

\author{
Submitted: \\ 26 Desember 2019 \\ Revision: \\ 13 Februari 2020 \\ Accepted: \\ 18 Februari 2020
}

\begin{abstract}
This study aims to find out relationship between authoritative parenting perceptions with gadget addiction in early adolescents. The population in this study was the early adolescents class VIII SMP X in Sleman Regency in the Academic Year 2019/2020 with a total sample of 128 students. Analysis of the data used is to use Product Moment Analysis through SPSS 17 for Windows. The results of data analysis showed there was a negative and significant relationship between authoritative parenting perceptions with gadget addiction in early adolescents, the correlation coefficient value was -0.193 with a significance value $(\mathrm{p})$ of $0.000(\mathrm{p}<0.01)$ which meant the first hypothesis in this study accepted. The results of this study can be concluded that there is a significant negative relationship between authoritative parenting perceptions with gadget addiction in early adolescents. The higher the authoritative parenting perceptions then gadget addiction tends to be lower. Conversely, the lower the authoritative parenting perceptions, the gadget addiction tends to be higher.
\end{abstract}

Keyword: Authoritative parenting perceptions; Early adolescents; Gadget addiction.

\begin{abstract}
ABSTRAK
Penelitian ini bertujuan untuk mengetahui hubungan antara persepsi pola asuh demokratis dengan kecanduan gadget pada remaja awal. Populasi dalam penelitian ini remaja awal kelas VIII SMP X di Kabupaten Sleman Tahun Ajaran 2019/2020 dengan jumlah sampel sebanyak 128 siswa. Analisis data yang digunakan adalah Analisa Product Moment melalui bantuan SPSS 17 for Windows Hasil analisis data menunjukkan ada hubungan negatif dan signifikan antara persepsi pola asuh demokratis dengan kecanduan gadget pada remaja awal, nilai koefisien korelasi sebesar -0,193 dengan nilai signifikansi (p) sebesar 0,000 ( $\mathrm{p}<0,01)$ artinya hipotesis dalam penelitian ini diterima. Hasil penelitian ini dapat disimpulkan bahwa ada hubungan negatif yang signifikan antara persepsi pola asuh demokratis dengan kecanduan gadget pada remaja awal. Semakin tinggi persepsi pola asuh demokratis maka kecanduan gadget cenderung semakin rendah. Sebaliknya semakin rendah persepsi pola asuh demokratis maka kecanduang gadget cenderung semakin tinggi.
\end{abstract}

Kata Kunci: Persepsi pola asuh demokratis; Kecanduan gadget; Remaja awal.

\footnotetext{
${ }^{1}$ Sri Widayani, Magister Psikologi, Universitas Mercu Buana Yogyakarta, Email : bundayani04@gmail.com

${ }^{2}$ Kamsih Astuti, Universitas Mercu Buana Yogyakarta, Email : tutik.umby@gmail.com
} 


\section{PENDAHULUAN}

Kebutuhan akan komunikasi dan informasi di era revolusi industri 4.0 merupakan hal yang penting bagi semua kalangan masyarakat. Komunikasi dan informasi menggunakan gadget merupakan hal yang tidak dapat ditinggalkan dalam kehidupan dari anak-anak sampai orang tua. Hampir setiap individu mulai dari remaja hingga orang tua kini memiliki gadget.

Gadget atau gawai merupakan suatu piranti atau instrumen yang memiliki tujuan dan fungsi praktis yang dirancang secara spesifik lebih canggih dibandingkan dengan tehnologitehnologi sebelumnya. Contoh gadget adalah laptop, ipad, tablet atau smartphone (Wijanarko \& Setiawati, 2016). Dengan jaringan internet, gadget dengan berbagai aplikasi di dalamnya merupakan barang canggih yang dapat menyajikan berbagai media berita, bisnis, jejaring sosial, hobi, bahkan hiburan (Marpaung, 2018).

Gagdet tidak hanya digunakan oleh kalangan dewasa, di Indonesia siswa sekolah dasar pun sudah pandai menggunakan gadget. Gadget dengan jaringan internet dapat membantu siswa menemukan berbagai informasi untuk menopang pengetahuan mereka di sekolah, namun kenyataannya hanya sedikit pelajar yang memanfaatkan gagdet untuk hal tersebut, pada umumnya gagdet mereka miliki digunakan untuk, main game, mendengarkan musik, menonton tayangan audio-visual, mengakses facebook, sms dll, sehingga berpengaruh terhadap prestasi belajarnya di sekolah (Rozalia, 2017).

Studi yang dilakukan Kominfo dan UNICEF yang berjudul Digital Citizenship Safety among Children and Adolescents in Indonesia menunjukkan bahwa media digital merupakan saluran komunikasi utama yang digunakan remaja dan 30 juta anak-anak dan remaja di Indonesia merupakan pengguna internet. Anak-anak dan remaja cenderung menggunakan smartphone, komputer, dan laptop dalam kegiatan sehari-hari. (Kominfo, 2014).

Gadget dengan sambungan internet di dalamnya merupakan perangkat elektronik yang dengan mudah dapat digunakan remaja untuk mencari berbagai informasi yang dibutuhkan yang berkaitan dengan pembelajaran mereka di sekolah namun gadget dengan sambungan internet bersifat interaktif dan menyediakan berbagai link/situs yang menarik bagi remaja, sehungga remaja tergoda untuk mengkliknya dan membuat pencarian informasi terkait pembelajaran terbengkalai dan lepas kendali (Rozalia, 2017).

Penggunaan gadget yang tinggi pada remaja membuat aktivitas dan pola perilaku keseharian remaja juga berubah. Fenomena umum yang terjadi sekarang, remaja dengan gadget yang dimilikinya cenderung asik dengan kehidupan dunia maya mereka dan perhatian yang lebih sedikit pada kehidupan nyata mereka. Remaja cenderung acuh terhadap lingkungannya (Agusta, 2016). Berdasarkan observasi di lapangan, ketika remaja sedang beraktivitas bersama keluarga maupun kerabat, mereka asyik menggunakan gadget-nya. Sering kali terlihat remaja yang berjalan dengan tetap fokus menatap layar gadget, selalu membawa gadget miliknya, dan membawa pengisi daya kemanapun remaja pergi. Salah satu dampak negatif penggunaan gadget yang tinggi pada remaja akan mengakibatkan kecanduan atau ketergantungan (Karuniawan \& Cahyanti, 2013).

Menurut Erikson (dalam Upton, 2012), masa remaja merupakan masa krisis identitas . Krisis identitas merupakan periode perkembangan identitas dimana individu akan melakukan eksplorasi terhadap berbagai alternatif (Santrock, 2012). Pada periode perkembangan ini, remaja memiliki rasa ingin tahu yang tinggi, ingin mencoba hal-hal baru, dan mudah terpengaruh oleh teman sebayanya (Sarwono dalam Sari, 2017)). Keberadaan gadget menjadikan remaja seperti menemukan sarana untuk memenuhi kebutuhannya, seperti kebutuhan bersosialisasi, pertemanan, mengakses berbagai informasi, hiburan, dan berbagai aktifitas yang dapat menghasilkan uang (Marpaung, 2018). Gadget memiliki konten-konten yang baik untuk perkembangan remaja, namun jika berlebihan dan tidak selektif dapat 
berdampak buruk dan berpengaruh terhadap prestasi belajar remaja di sekolah (Rusmini, 2016). Penggunaan gadget pada remaja memiliki dampak positif dan negatif. Perlu perhatian yang intens bagi para orangtua dan pendidik agar tidak terjadi pergeseran perubahan pola-pola perilaku remaja yang diakibatkan oleh kecanduan gadget (Arifin, 2015).

Berbagai penelitian tentang kecanduan gadget telah membuktikan dampak negatif kecanduan gadget pada pola perilaku remaja dalam keseharian seperti menurunnya minat belajar, disiplin belajar, gangguan emosi dan perilaku serta kemampuan bersosialisasi.

Banyak faktor yang dapat mempengaruhi kecanduan gadget pada remaja, diantaranya adalah pola asuh orang tua. Pola asuh adalah cara-cara yang khas yang orang tua pikirkan, rasakan, dan lakukan dalam hal membesarkan anak. Pola asuh orang tua akan dipersepsi oleh anak. Kekeliruan dalam mengasuh dan membesarkan anak, yang tidak sesuai dengan perkembangan anak akan berpengaruh buruk terhadap perilakunya. Pola asuh demokratis pada remaja akan menumbuhkan rasa tanggung jawab anak, termasuk tanggung jawab dalam penggunaan gadget (Widiastuti \& Elshap, 2015).

Berdasarkan latar belakang masalah yang telah diuraikan di atas, maka penelitian ini bertujuan untuk melihat hubungan antara persepsi pola asuh demokratis orang tua terhadap kecanduan gadget pada remaja awal di era revolusi industri 4.0

\section{METODE PENELITIAN}

Penelitian ini terdiri dari dua variabel yaitu persepsi pola asuh demokratis sebagai variabel bebas dan kecanduan gadget sebagai variabel terikat. Subjek dalam penelitian ini adalah 128 remaja awal kelas VIII SMP X di Kabupaten Sleman Tahun Ajaran 2019/2020. Metode pengambilan sampel yang digunakan adalah probability sampling dengan teknik cluster random sampling yaitu melakukan randomisasi terhadap kelompok bukan terhadap subjek secara individual (Azwar, 2016). Pengambilan sampel dilakukan secara acak dengan pengundian kelas, karena jumlah siswa masing-masing kelas relatif sama.

Metode yang digunakan untuk mengumpulkan data adalah metode kuantitatif dengan menggunakan skala sebagai alat pengumpul data. Skala yang digunakan adalah skala persepsi pola asuh demokratis dan skala kecanduan gadget. Jenis skala yang digunakan adalah skala Likert.

Skala persepsi pola asuh demokratis dalam penelitian ini disusun berdasarkan aspekaspek pola asuh demokratis yang dikemukakan oleh Baumrind (dalam Soetjiningsih, 2018) yaitu : (1) melakukan kontrol terhadap remaja tapi tidak terlalu ketat, (2) bersikap tegas dan memberikan penjelasan mengenai aturan, (3) mau bermusyawarah atau berdiskusi, (4) bersifat sayang dan hangat pada remaja, (4) menunjukkan dukungan dan rasa senang terhadap perilaku konstruktif remaja. Skala persepsi pola asuh demokratis berjumlah 32 aitem dengan daya beda dari 0,348-0,657 dengan reliabilitas koefisien Alpha Cronbach sebesar 0,902. Skala kecanduan gadget dalam penelitian ini disusun berdasarkan aspek-aspek kecanduan gadget yang dikemukakan oleh Caplan (dalam Young \& Abreu, 2017) yaitu saliance, modifikasi mood (suasana perasaan), tolerance, withdrawal, konflik dan relapse. Skala kecanduan gadget berjumlah 33 aitem dengan daya beda dari 0,303-0,615 dengan reliabilitas koefisien Alpha Cronbach sebesar 0,889.

Metode analisis data yang digunakan pada penelitian ini menggunakan uji statistik korelasi produk momen.

\section{HASIL DAN PEMBAHASAN}

Analisis data dilakukan menggunakan SPSS 17 for window. Sebelum melakukan analisis data, dilakukan uji prasyarat yaitu uji normalitas data dan uji liniearitas. 
SRI WIDAYANI \& KAMSIH ASTUTI, Pembentukan Karakter Melalui Pola Asuh Demokratis Untuk Mencegah Kecanduan Gadget Remaja Di Era Revolusi Industri 4.0

Tabel 1.

Hasil Uji Normalitas

\begin{tabular}{lcccc}
\hline \multirow{2}{*}{ Variabel } & Kolmogorov-Smirnov test & $\mathrm{p}$ & Subyek & \multirow{2}{*}{ Keterangan } \\
\cline { 2 - 4 } $\begin{array}{l}\text { Persepsi Pola Asuh } \\
\text { Demokratis }\end{array}$ & 0,627 & 0,827 & 128 & Normal \\
\hline Kecanduan Gadget & 0,795 & 0,553 & 128 & Normal \\
\hline
\end{tabular}

Uji normalitas dilakukan untuk mengetahui apakah variabel-variabel yang diteliti berdistribusi normal atau tidak. Uji normalitas dilakukan menggunakan uji Kolmogorov Smirnov Test. Data dikatakan berdistribusi normal jika $\mathrm{p}>0.05$ (Siregar, 2017). Uji normalitas yang dilakukan terhadap variabel persepsi pola asuh demokratis nilai Kolmogorov-Smirnov test sebesar 0,627 dan $\mathrm{p}=0,827$ ( $\mathrm{p}>0,05)$ hal tersebut menunjukan bahwa variabel persepsi pola asuh demokratis berdistribusi normal. Uji normalitas pada variabel kecanduan gadget diperoleh nilai Kolmogorov-Smirnov test sebesar 0,795 dan $\mathrm{p}=$ 0,553 ( $\mathrm{p}>0,05)$ hal tersebut menunjukan bahwa variabel Kecanduan gagdet berdistribusi normal.

Tabel 2.

Hasil Uji Linearitas Hubungan

\begin{tabular}{llccc}
\hline Variabel & \multirow{2}{*}{$\begin{array}{l}\text { Variabel Independen } \\
\text { Dependen }\end{array}$} & \multicolumn{2}{c}{ Nilai } & \multirow{2}{*}{ Keterangan } \\
\cline { 2 - 4 } $\begin{array}{l}\text { Kecanduan } \\
\text { Gadget }\end{array}$ & Persepsi Pola Asuh & 5,090 & 0,027 & \multirow{2}{*}{ Linier } \\
\hline
\end{tabular}

Uji linieritas dilakukan untuk mengetahui apakah dua variabel yang dianalisis korelasinya mempunyai hubungan linier atau tida. Jika $\mathrm{p}<0,05$ maka variabel memiliki hubungan yang linier. Jika p>0,05 maka variabel tidak memiliki hubungan yang linier (Siregar, 2017). Berdasarkan tabel 2. dapat dikatakan bahwa variabel persepsi pola asuh demokratis dan kecanduan gadget memiliki hubungan yang linear. Hal tersebut dapat dilihat dari nilai $\mathrm{p}$ yang diperoleh yaitu 0.027 ( $\mathrm{p}<0.05$ ), dapat disimpulkan bahwa kedua variabel memiliki hubungan linear dan telah memenuhi syarat untuk dilakukan analisa korelasi product moment.

Selanjutnya dilakukan uji hipotesis untuk mengetahui hubungan antara variabel persepsi pola asuh demokratis dengan variabel kecanduan gadget. Uji hipotesis dilakukan menggunakan uji korelasi product moment. Hasil uji hopetesis dapat dilihat pada tabel 3.

Tabel 3.

Hasil Uji Hipotesis

\begin{tabular}{lllll}
\hline Variabel Terikat & Variabel Bebas & Koef. Korelasi & Sig. & Keterangan \\
\hline $\begin{array}{l}\text { Kecanduan } \\
\text { Gadget }\end{array}$ & $\begin{array}{l}\text { Persepsi Pola } \\
\text { Asuh Demokratis }\end{array}$ & $-0,193$ & 0,000 & Signifikan
\end{tabular}

Hasil uji hipotesis pada 128 remaka awal kelas VIII SMP X di Kabupaten Sleman Tahun Ajaran 2019/2020 yang menjadi subjek penelitian, diperoleh hasil bahwa ada ada hubungan negatif yang signifikan antara persepsi pola asuh demokratis dengan kecanduan 
gadget dengan koefisien korelasi Product Moment sebesar $r=-0,193$ (negatif) dan nilai signifikansi (p) sebesar 0,000 ( $<<0,01)$, artinya semakin tinggi persepsi pola asuh demokratis maka kecanduan gadget cenderung semakin rendah, dan sebaliknya semakin rendah persepsi pola asuh demokratis maka kecanduan gadget cenderung semakin tinggi.

Berdasarkan hasil pengujian hipotesis dalam penelitian ini, menunjukkan bahwa ada hubungan negatif antara persepsi pola asuh demokratis dengan kecanduan gadget pada remaja awal. Pernyataan pada hipotesis tersebut dapat diterima melalui hasil analisis menggunakan teknik analisis korelasi product moment, menunjukkan angka korelasi sebesar 0,193 dengan nilai signifikansi (p) sebesar 0,000 ( $<<0,01)$. Hasil hipotesis ini mengandung pengertian bahwa ada hubungan negatif yang signifikan antara persepsi pola asuh demokratis dengan kecanduan gadget pada remaja awal. Penelitian ini menunjukkan bahwa persepsi remaja awal tentang pola asuh demokratis orang tua memiliki kaitan dengan perilaku kecanduan gadget yang dilakukan remaja. Semakin tinggi persepsi pola asuh demokratis maka kecanduan gadget cenderung semakin rendah. Sebaliknya semakin rendah persepsi pola asuh demokratis maka kecanduang gadget cenderung semakin tinggi.

Studi yang dilakukan oleh Abedini, dkk (2012) menyatakan bahwa pola asuh demokratis memiliki hubungan negatif signifikan dengan kecanduan gagdet. Remaja bertingkah laku sesuai apa yang dipelajari di lingkungan. Keluarga merupakan lingkungan yang paling dekat bagi remaja, maka remaja dalam mengambil keputusan dan bertingkah laku (apa yang boleh dan apa yang tidak, mana yang baik dan mana yang salah) sangat dipengaruhi pada pengamatan mereka tentang apa yang terjadi dalam keluarganya. Pandangan, sikap dan tingkah laku orang tua mempengaruhi pembentukan tingkah laku remaja di masa yang akan datang (Kurnia, dalam Nugraheni, 2017).

Pola asuh yang diterapkan orang tua berpengaruh terhadap karakter dan perilaku remaja. Orang tua yang menerapkan pola asuh demokratis akan melakukan kontrol terhadap perilaku remaja, bersikap tegas terhadap remaja, memberikan aturan-aturan yang berkaitan dengan perilakunya, namun orang tua juga memberikan penjelasan kepada remaja mengenai aturan tersebut. Penjelasan dan pemahaman yang diberikan orang tua terhadap peraturan yang ditetapkan kepada remaja mengapa suatu peraturan dibuat, dan mengapa remaja diharapkan untuk bertingkah laku tertentu sangat bermanfaat bagi remaja untuk belajar memikirkan perilaku-perilakunya, apakah baik atau tidak baik untuk dilakukannya. Sifat hangat dan sayang orang tua terhadap remaja, serta rasa senang dan dukungan orang tua terhadap perilaku konstruktif remaja akan menumbuhkan rasa percaya diri dan sikap kooperatif remaja terhadap lingkungannya.

Orang tua mau bermusyawarah atau berdiskusi terhadap segala keputusan dan permasalahan yang terjadi, sehingga remaja belajar bersikap kritis dalam menghadapi permasalahan dan mengambil keputusan terkait dengan perilakunya (Soetjiningsih, 2018). Orang tua dengan pola asuh yang otoritatif, tidak memaksakan kepercayaan mereka, tetapi sebaliknya memberikan mereka alasan dan penjelasan untuk mengadopsi perilaku, tindakan, dan nilai tertentu membuat remaja lebih mudah menerima pengaruh orang tua termasuk perilaku, tindakan dan nilai tertentu dalam menggunakan gadget ((Moazedian, dkk, 2014).

Remaja yang mempunyai orang tua demokratis memiliki kompetensi secara sosial, percaya diri, dan bertanggung jawab. Hal tersebut karena remaja menilai bahwa tuntutan orang tuanya terhadap disiplin dan peraturan adalah adil dan masuk akal, sehingga remaja menjadi lebih penurut dan bertanggungung jawab terhadap tugas dan kewajibannya. Komunikasi efektif yang dilakukan orang tua di mana remaja diberikan kesempatan untuk berpendapat mengenai peraturan yang diterapkan di rumah, membuat remaja mudah menginternalisasi, dan menerima nilai serta peraturan. Remaja tanpa terpaksa akan menjalankan nilai dan peraturan dengan sepenuh hati. Ketika remaja menjalankan tugas dan 
kewajibannya tanpa paksaan sesuai dengan kemauannya sendiri, maka remaja belajar mengatur dirinya dan disiplin dalam menggunakan gagdet (Nugraheni, 2017).

Pola asuh orang tua dalam keluarga sebagai lingkungan pertama remaja berperanan sangat penting dalam membentuk perilaku kecanduan gadget. Pola asuh orang tua akan mempengaruhi karakter remaja, sikap, cara berpikir, dan berperilaku (Anisah, 2011) . Pemberian pola asuh yang tepat, yang dapat mengupayakan remaja menjadi pribadi yang utuh dan berkarakter, akan mempengaruhi sikap, cara berpikir dan berperilaku remaja dalam menggunakan gadget. Baumrind (dalam Bibi dkk, 2013), mengemukakan bahwa orang tua, melalui pengaruh mereka, pada dasarnya membentuk remaja menjadi orang dewasa. Pola asuh demokratis orang tua yang merupakan keseluruhan interaksi orang tua untuk mengubah tingkah laku, pengetahuan, dan nilai-nilai remaja dengan memberikan dorongan kepada remaja agar dapat tumbuh dan berkembang secara optimal merupakan pola asuh yang paling sesuai untuk remaja. (Tridhonanto, 2014).

Menurut Baumrind (dalam Soetjiningsih, 2018), pengasuhan otoritatif (demokratis ) yaitu pola asuh orang tua yang mendorong remaja untuk mandiri namun tetap memberikan batasan dan kendali atas tindakan-tindakan remaja, memberikan kesempatan pada remaja untuk berdialog, bersifat hangat dan mengasuh serta menunjukkan rasa senang dan dukungan terhadap tingkah laku konstruktif remaja akan memberikan pengaruh kepada anak sehingga mempunyai kompetensi sosial, percaya diri, bertanggung jawab, bisa mengendalikan diri, mandiri dan mampu mengatasi stress dengan baik.

Kecanduan gadget pada remaja dipengaruhi persepsi pola asuh orang tua yang diterapkan untuk merawat remaja. Gaya pengasuhan sangat terkait dengan perilaku menyimpang remaja, kecanduan, dan masalah psikologis. Pola asuh yang baik dan positif sangat terkait dengan pencegahan kenakalan remaja, psikologis, disfungsi dan kecanduan perilaku (Ching \& Tak, 2017). Gaya pengasuhan demokratif menghasilkan kemampuan yang mengarah pada kontrol impuls yang lebih tinggi dan keterampilan penetapan tujuan, sehingga mempengaruhi kecanduan gagdet.

\section{KESIMPULAN}

Kesimpulan dari penelitian ini, ada hubungan negatif yang signifikan antara persepsi pola asuh demokratis dengan kecanduan gadget pada remaja awal kelas VIII SMP X di Kabupaten Sleman Tahun Ajaran 2019/2020 artinya semakin tinggi persepsi pola asuh demokratis maka kecanduan gadget cenderung semakin rendah, dan sebaliknya semakin rendah persepsi pola asuh demokratis maka kecanduang gadget cenderung semakin tinggi. Saran bagi orant tua untuk menerapkan pola asuh demokratis dalam pengasuhan terhadap remaja awal. Pola asuh yang demokratis, yang tidak memaksakan kepercayaan mereka, namun memberikan alasan dan penjelasan untuk mengadopsi perilaku, tindakan, dan nilai tertentu, membuat remaja lebih mudah menerima pengaruh orang tua. termasuk perilaku, tindakan dan nilai tertentu dalam menggunakan gadget. Saran bagi peneliti selanjutnya untuk meneliti faktor-faktor lainnya seperti stress akademik, kemampuan bersosialisasi, kondisi keluarga dan lingkungan.

\section{DAFTAR PUSTAKA}

Abedini, Y., Zamani, B., Kheradmand, A., \& Rajabizadeh, G. (2012). Impacts of Mothers' Occupation Status and Parenting Styles On Levels of Self-control, Addiction to Computer Games, and Educational progress of Adolescents. European Psychiatry, 4, 102-110. https://doi.org/10.1016/s0924-9338(15)30399-0. 
Agusta, D. (2016). Faktor-Faktor Resiko Kecanduan Menggunakan Smartphone Pada Siswa Di SMK Negeri 1 Kalasan Yogyakarta. E-Journal Bimbingan Dan Konseling, 5, 8696. https://doi.org/10.4172/2167-1044.1000296.

Anisah, A. S. (2011). Pola Asuh Orang Tua dan Implikasinya Terhadap Pembentukan Karakter Anak. Jurnal Pendidikan Universitas Garut, 5, 70-84. Retrieved from https://journal.uniga.ac.id/index.php/JP/article/viewFile/43/43.

Arifin, Z. (2015). Perilaku Remaja Pengguna Gagdet; Analisis Teori Sosiologi Pendidikan. Jurnal Pemikiran Keislaman, 26, 287-316. https://doi.org/10.33367/tribakti.v26i2.219.

Azwar, S. (2016). Metode Penelitian. Yogyakarta: Pustaka Pelajar.

Bibi, F., Chaudhry, A. G., Awan, E. A., \& Tariq, B. (2013). Contribution of Parenting Style in life domain of Children. IOSR Journal Of Humanities And Social Science (IOSRJHSS), 12, 91-95.

Ching, K. H, \&Tak, L. M. (2017). The Structural Model in Parenting Style, Attachment Style, Self-regulation and Self-esteem for Smartphone Addiction. IAFOR Journal of Psychology \& the Behavioral Sciences, 3, 85-103. https://doi.org/10.22492/ijpbs.3.1.06

Karuniawan, A., \& Cahyanti, I. Y. (2013). Hubungan antara Academic Stress dengan Smartphone Addiction pada Mahasiswa Pengguna Smartphone. Jurnal Psikologi Klinis Dan Kesehatan Mental, 2, 16-21.

Kominfo. (2014). Riset Kominfo dan UNICEF Mengenai Perilaku Anak dan Remaja Dalam Menggunakan Internet. https://kominfo.go.id/index.php/content/detail/3834/Siaran+Pers+No.+17-PIHKOMINFO-2-2014+tentang+Riset+Kominfo+dan+UNICEF+Mengenai+ Perilaku+Anak+dan+Remaja+Dalam+Menggunakan+Internet+/0/siaran_pers.

Marpaung, J. (2018). Pengaruh Penggunaan Gagdet Dalam Kehidupan. Jurnal KOPASTA, 5, 55-64.

Moazedian, A., Taqavi, S. A., Hosseinialmadani, S. A., Mohammadyfar, M. A., \& Sabetimani, M. (2014). Parenting Style and Internet Addiction. Journal Life Science Biomed, 4, 9-14.

Nugraheni, D. . (2017). Pola Asuh Orangtua Pada Remaja Yang Kecanduan Bermain Game Online. Diunduh dari httpe:prints.umm.ac.id/438421/jiptumm.

Rozalia, M. F. (2017). Hubungan Intensitas Pemanfaatan Gadget Dengan Prestasi Belajar Siswa Kelas V Sekolah Dasar. Jurnal Pemikiran Dan Pengembangan SD, 5, 722-731.

Rusmini. (2016). Gadget dan Prestasi Belajar pada Usia 13-15 Tahun di SMP Cahaya di Jl. Bulak Banteng Lor No. 68 Surabaya. Jurnal Ners Lentera, 4, 74-81.

Santrock, J. W. (2012). Perkembangan Masa Hidup. Jakarta: Erlangga. 
SRI WIDAYANI \& KAMSIH ASTUTI, Pembentukan Karakter Melalui Pola Asuh Demokratis Untuk Mencegah Kecanduan Gadget Remaja Di Era Revolusi Industri 4.0

Sari, A. P., Ilyas, A., \& Ifdil, I. (2018). Tingkat Kecanduan Internet pada Remaja Awal. JPPI (Jurnal Penelitian Pendidikan Indonesia), 3, 45. https://doi.org/10.29210/02018190.

Siregar, S. (2017). Statistik Parametrik Untuk Penelitaian Kuantitatif. Jakarta: Bumi Aksara.

Soetjiningsih, C. H. (2018). Perkembangan Anak Sejak Pembuahan Sampai Kanak-Kanak Akhir. Depok: Pranadamedia Group.

Tridhonanto, A. (2014). Mengembangkan Pola Asuh Demokratis. Jakarta: PT Elex Media Komputindo Kelompok.

Upton, P. (2012). Psikologi Perkembangan. Jakarta: Erlangga.

Widiastuti, N., \& Elshap, D. S. (2015). Pola Asuh Orang Tua Sebagai Upaya Menumbuhkan Sikap Tanggung Jawab Pada Anak Dalam Menggunakan Teknologi Komunikasi. P2M STKIP Siliwangi, 2, 148. https://doi.org/10.22460/p2m.v2i2p148-159.174

Wijanarko, J., \& Setiawati, E. (2016). Ayah Ibu Baik Parenting Era Digital Pengaruh Gadget pada Perilaku dan Kemampuan Anak. Jakarta: Keluarga Indonesia Bahagia.

Young, K. S., \& Abreu, C. N. de. (2017). Kecanduan Internet. Panduan Konseling dan Petunjuk untuk Evaluasi dan Penanganannya. Yogyakarta: Pustaka Pelajar. 